\title{
Evidence-based clinical advice for nutrition and dietary weight loss strategies for the management of NAFLD and NASH
}

\author{
Theresa J. Hydes', Sujan Ravi', Rohit Loomba², and Meagan E. Gray ${ }^{1}$ \\ 'Division of Gastroenterology and Hepatology, University of Alabama at Birmingham, Birmingham, AL; ${ }^{2}$ Division of Gastroenterology, \\ University of California, San Diego, La Jolla, CA, USA
}

\begin{abstract}
Nonalcoholic fatty liver disease (NAFLD) is the most common cause of chronic liver disease worldwide and affects approximately one third of adults in the United States. The disease is becoming a global epidemic as a result of the rising rates of obesity and metabolic disease. Emerging data suggest weight loss of $\geq 10 \%$ overall body weight is beneficial in resolving steatosis and reversing fibrosis. Prospective trials comparing various diets are limited by lack of sufficient power as well as pre- and post-treatment histopathology, and therefore no specific diet is recommended at this time. In this narrative review we examine the pathophysiology behind specific macronutrient components that can either promote or reverse NAFLD to help inform more specific dietary recommendations. Overall, the data supports reducing saturated fat, refined carbohydrates, and red and processed meats in the diet, and increasing the consumption of plant-based foods. Diets that incorporate these recommendations include plant-based diets such as the Dietary Approaches to Stop Hypertension, Mediterranean, vegetarian, and vegan diets. (Clin Mol Hepatol 2020;26:383-400)
\end{abstract}

Keywords: Diet, Vegetarian; Diet, Healthy; Nonalcoholic fatty liver disease; Diet

\section{INTRODUCTION}

Nonalcoholic fatty liver disease (NAFLD) encompasses a spec- trum of disorders ranging from simple steatosis to steatohepatitis. NAFLD is the most common cause of chronic liver disease worldwide, affecting approximately $25 \%$ of the adult population in the

\footnotetext{
Abbreviations:

ALT, alanine aminotransferase; BCAA, branched chain amino acids; BMI, body mass index; $\mathrm{CHO}$, carbohydrates; DASH, Dietary Approaches to Stop Hypertension; DNL, de novo lipogenesis; EASL, European Association for the Study of the Liver; FFAs, free fatty acids; FGF21, fibroblast growth factor 21; FLI, fatty liver index; HCC, hepatocellular carcinoma; HOMA-IR, Homeostatic Model Assessment of Insulin Resistance; IF, intermittent fasting; IHLC, intrahepatic lipid content; LDL, low-density lipoprotein; mTOR, mammalian target of rapamycin; MUFA, monounsaturated fatty acids; NAFLD, nonalcoholic fatty liver disease; NAS, NAFLD activity score; NASH, nonalcoholic steatohepatitis; NutriRECS, Nutritional Recommendations; PPAR, peroxisome proliferator-activated receptor; PUFAs, polyunsaturated fatty acids; RCT, randomized controlled trial; SFAs, saturated fatty acids; SREBP-1c, sterol regulatory element-binding protein1c; SSBs, sugar-sweetened beverages; T2DM, type 2 diabetes mellitus; TMA, trimethylamine; TMAO, trimethylamine N-oxide; US, United States; VAT, visceral adipose tissue; VLDL, very low-density lipoprotein
}

\section{Corresponding author: Meagan E. Gray}

Division of Gastroenterology and Hepatology, University of Alabama at Birmingham, BDB 395A, 1720 2nd Ave. S., Birmingham, AL 35294-0012, USA

Tel: +1-205-975-9698, Fax: +1-205-975-9777

E-mail: grayme@uab.edu

https://orcid.org/0000-0001-7556-8985 
United States (US) and globally. ${ }^{1}$ Approximately $25 \%$ of patients with NAFLD have nonalcoholic steatohepatitis (NASH), which is associated with a $20 \%$ risk of progression to cirrhosis. ${ }^{2}$ It is estimated that NAFLD affects $40-70 \%$ of patients with type 2 diabetes mellitus (T2DM), ${ }^{2-4} 67 \%$ of adults with a body mass index (BMI) between 25 and $30 \mathrm{~kg} / \mathrm{m}^{2}$, and up to $91 \%$ of adults with a $\mathrm{BMI}>30 \mathrm{~kg} / \mathrm{m}^{5.9}$

The diagnosis of NAFLD requires $>5 \%$ hepatic steatosis with lack of secondary cause for hepatic fat accumulation. Steatosis results from a surplus of free fatty acids (FFAs) either from excessive lipolysis $(60 \%)$, de novo lipogenesis (DNL, 25\%), dietary FFA $(15 \%)$, diminished export by very low-density lipoprotein (VLDL), or impaired beta-oxidation (Fig. 1). ${ }^{10}$ Excess FFAs are stored as triglycerides in the hepatocytes. In NAFLD, peripheral lipolysis is resistant to suppression by insulin, further increasing serum FFA levels." Lipotoxicity, along with oxidative stress and a pro-inflammatory environment, lead to NASH. ${ }^{12}$

Due to lack of approved pharmacologic therapy, current treatment recommendations for NASH are for weight loss of $\geq 10 \%$ total body weight, which is associated with resolution of steatohepatitis and fibrosis regression. ${ }^{13-15}$ Prospective trials comparing various diets are limited by lack of sufficient power as well as preand post-treatment histopathology. ${ }^{13}$ As a result, the American Association for the Study of Liver Disease has not made any specific dietary recommendation for NAFLD at this time. While guidelines from the European Association for the Study of the Liver
(EASL) recommend exclusion of NAFLD-promoting components (processed food, high fructose foods and beverages) in addition to a macronutrient composition in line with a Mediterranean diet, this recommendation is only supported by evidence graded as "moderate" in quality. ${ }^{14}$ Here we review the pathophysiology behind how the quality of proteins, carbohydrates ( $\mathrm{CHOS}$ ), and fats can promote or reverse NAFLD, the available data on specific diets, and discuss ongoing knowledge gaps for future research.

\section{ENERGY AND CALORIC RESTRICTION}

\section{Observational studies}

The diabetes, obesity and NAFLD epidemics are products of a significant rise in net population energy intake, resulting from energy-dense foods and a sedentary lifestyle. A high-calorie diet is fundamentally linked to obesity and is the initial trigger point for NAFLD through adipose tissue expansion, increased inflammation and mitochondrial dysfunction. It is often imbalanced with high quantities of saturated fatty acids (SFAs), refined CHOs, sugarsweetened beverages (SSBs) and alcohol excess. Understanding the individual impact of these factors is therefore a challenge for clinical trial design, and limits our understanding of the role of specific macronutrients outside the context of excess energy intake. In terms of observational studies, a cohort study of 55 patients

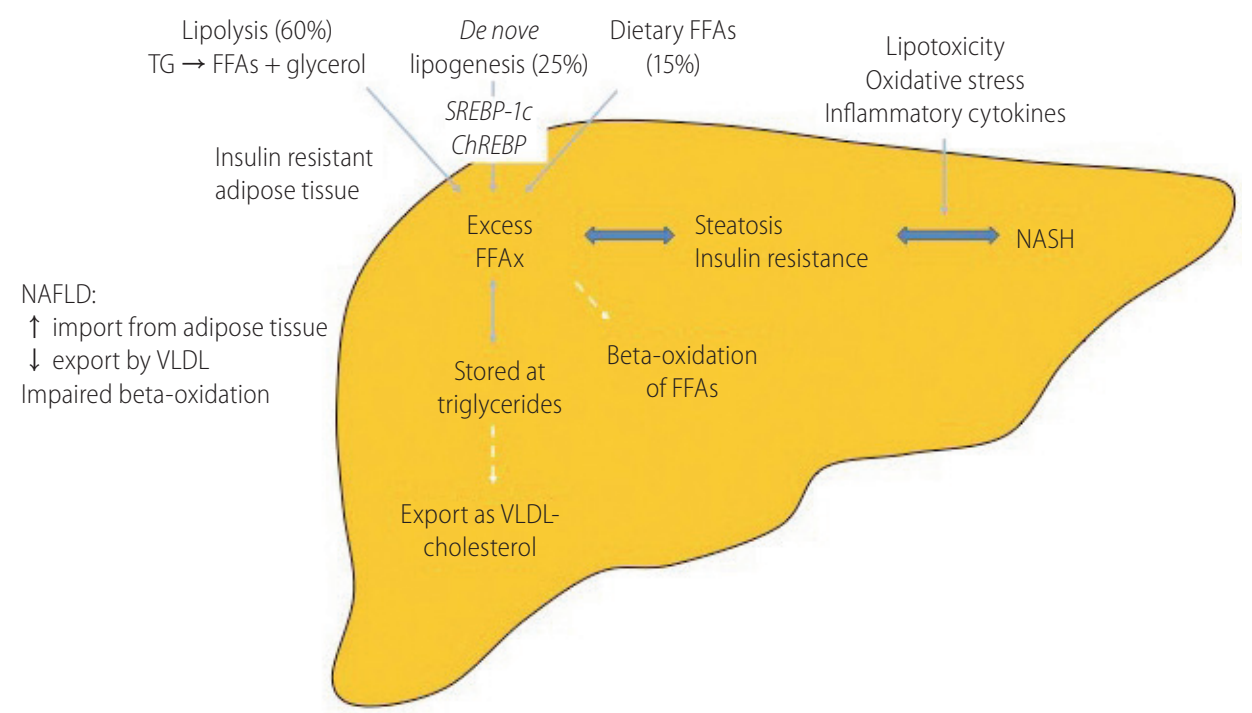

Figure 1. The pathogenesis of NAFLD. TG, triglycerides; FFAs, free fatty acids; SREBP-1c, sterol regulatory element-binding protein-1c; ChREBP, carbohydrate response element-binding protein; NASH, nonalcoholic steatohepatitis; NAFLD, nonalcoholic fatty liver disease; VLDL, very low density lipoprotein. 
with NAFLD and 88 healthy controls observed that NAFLD patients consumed more calories overall (2,739 vs. 2,173 kcal), however the macronutrient composition (fat, $\mathrm{CHO}$, fructose) was largely comparable between groups. ${ }^{16}$ Given this, energy restriction, and thereby weight loss, plays a crucial role in the treatment of these patients. The largest prospective trial to date in this field followed 293 patients with biopsy-proven NASH for 52 weeks. Patients were advised to follow a low fat, hypocaloric diet which contained $750 \mathrm{kcal} /$ day less than their daily energy needs, in addition to walking 200 minutes per week. ${ }^{15}$ Overall 19\% had fibrosis regression, $47 \%$ had reduction in NAFLD activity score (NAS) on histology and $25 \%$ achieved complete resolution of steatohepatitis. The highest rates of fibrosis regression, NAS reduction and NASH resolution occurred in patients achieving $\geq 10 \%$ weight loss, however benefits were also seen for weight loss of $\geq 5 \%$. Using nutritional counselling, a small study of 15 patients with biopsy-proven NASH and a BMI $>25$ found histologic improvement to be associated with greater weight reduction. ${ }^{17}$ After 1 year of calorie restriction (mean reduction of $195 \mathrm{kcal} / \mathrm{day}$ ), nine patients had histologic improvement and six had stable NAS. Histological improvement was associated with greater changes in weight reduction.

\section{Pathophysiology}

A high-caloric diet leads to adipose tissue expansion, one of the sentinel events in the pathogenesis of NAFLD. Visceral adipose tissue (VAT) is particularly biological active. Excess accumulation of VAT increases the production of FFAs through reduced insulin sensitivity, leading to increased fatty acid influx into the liver, DNL and insulin resistance. Hypertrophy and hyperplasia of adipocytes results in hypoxemia and adipocyte dysfunction. ${ }^{18}$ This exacerbates insulin resistance and dyslipidemia, and creates a pro-inflammatory environment within the adipose tissue. The secretion of adipokines (adiponectin, resistin, leptin, visfatin) and pro-inflammatory cytokines (interleukins and tissue necrosis factor a) from VAT induce a state of systemic low-grade chronic inflammation which can promote the onset of NAFLD and NASH. ${ }^{18-20}$

\section{Randomized controlled trial data}

The findings from key randomized controlled trials (RCT) in this field involving lifestyle intervention for NAFLD and NASH are summarized in Table 1. ${ }^{21-24}$ Weight loss is consistently identified as being central to the metabolic benefits that result from calorie re- striction. A meta-analysis of therapeutic options for NAFLD, including lifestyle interventions, reported that weight loss of $\geq 7 \%$ (achieved by $<50 \%$ of patients even with intensive multi-disciplinary support) led to improved histological disease activity determined by NAS, although there was no impact on fibrosis. ${ }^{25}$

While guidelines currently recommend continuous energy restriction along with physical activity, ${ }_{1}^{26}$ there is increasing popular interest in intermittent fasting (IF), i.e., a low calorie period lasting less that 24 hours followed by a normal period of feeding. Evidence suggests that intermittent energy restriction results in equivalent weight loss compared to continuous energy restriction in the short-term, with a lack of long-term data. ${ }^{27}$ Several RCTs have looked at the effectiveness of IF in the setting of NAFLD. An 8 weeks modified alternate-day calorie restriction was found to lead to reductions in BMI, liver enzymes, liver steatosis and liver stiffness (based on shear wave elastography) compared to no intervention with adherence rates of $75-83 \%{ }^{28} \mathrm{~A}$ larger trial comparing alternate-day and time-restricted feeding with a control group for 12 weeks revealed that both diets led to significant short-term reductions in weight and improvements in dyslipidaemia, although no changes were seen for fasting levels of insulin or liver stiffness. ${ }^{29}$

\section{Clinical advice}

Calorie restriction with a 500-1,000 kcal daily deficit is an extremely effective lifestyle intervention for both the prevention of NAFLD and histological improvement in patients with established disease. The goal of calorie reduction should be to achieve $\geq 10 \%$ overall body weight loss.

\section{PROTEIN}

\section{Observational studies}

The consumption of animal protein, specifically red and processed meat, is associated with higher all-cause, cardiovascular and cancer-related mortality compared to plant protein. ${ }^{30-41}$ In a large US cohort, red and processed meats were associated with nine causes of death, with the strongest correlation being for mortality from chronic liver disease. ${ }^{34}$ High animal protein intake is also associated with NAFLD in overweight Caucasians independent of sociodemographic, lifestyle and metabolic traits. ${ }^{42}$ Animal protein is positively associated with high fatty liver index (FLI) 


\title{
CLINICAL and MOLECULAR
}

\author{
Volume_26 Number_4 October 2020
}

Table 1. Summary of randomized controlled trial data examining the influence of hypocaloric diets on hepatic steatosis

\begin{tabular}{|c|c|c|c|}
\hline Study & Participant & Intervention & Result \\
\hline Ueno et al. ${ }^{23}$ (1997) & $\begin{array}{l}\text { Obese adults } \\
\qquad\left(\mathrm{BMI}>25 \mathrm{~kg} / \mathrm{m}^{2} ; \mathrm{n}=25\right)\end{array}$ & $\begin{array}{l}\text { Randomized to receive the following } \\
\text { for } 3 \text { months: } 1 \text { ) hypocaloric diet } \\
\text { (ideal weight } \times 25 \mathrm{kcal} / \mathrm{kg} ; 50 \% \\
\text { carbohydrate, } 30 \% \text { fat) combined } \\
\text { with physical activity; 2) no } \\
\text { intervention }\end{array}$ & $\begin{array}{l}\text { The low calorie diet was associated with reductions } \\
\text { in weight, aminotransferases, albumin, } \\
\text { cholesterol and fasting glucose, in addition to } \\
\text { histologically determined levels of steatosis. } \\
\text { Improvements seen for other histological } \\
\text { parameters did not reach statistical significance. }\end{array}$ \\
\hline Kirk et al. ${ }^{24}$ (2009) & $\begin{array}{l}\text { Obese adults (mean } \\
\text { BMl, } 36.5 \pm 0.8 \mathrm{~kg} / \mathrm{m}^{2} \text {; } \\
\mathrm{n}=22 \text { ) }\end{array}$ & $\begin{array}{l}\text { Randomized to receive the following } \\
\text { for } 11 \text { weeks: 1) high carbohydrate } \\
\text { 1,000 kcal daily energy deficit diet; } \\
\text { 2) low carbohydrate } 1,000 \text { kcal daily } \\
\text { energy deficit diet }\end{array}$ & $\begin{array}{l}\text { IHTG content and insulin-mediated glucose uptake } \\
\text { were similar in both dietary groups after } 7 \% \\
\text { weight loss, i.e., calorie restriction and weight loss } \\
\text { more important than macronutrient composition } \\
\text { for these parameters. }\end{array}$ \\
\hline $\begin{array}{l}\text { Harrison et } \\
\text { al. }^{155}(2009)\end{array}$ & $\begin{array}{l}\text { Obese adults } \\
\left(\mathrm{BMI} \geq 27 \mathrm{~kg} / \mathrm{m}^{2}\right) \text { with } \\
\text { biopsy-proven NASH } \\
(\mathrm{n}=50)\end{array}$ & $\begin{array}{l}\text { Randomized to receive the following } \\
\text { for } 36 \text { weeks: 1) 1,400 kcal/day + } \\
\text { vitamin E } 800 \text { IU daily; 2) 1,400 } \\
\text { kcal/day + vitamin E } 800 \text { IU daily + } \\
\text { Orlistat } 120 \text { mg three times daily }\end{array}$ & $\begin{array}{l}\text { Weight loss ( } 6.0 \% \text { vs. } 8.3 \%, P=N S) \text {, reductions } \\
\text { in aminotransferases, hepatic steatosis, } \\
\text { necroinflammation, ballooning, and NAS were } \\
\text { similar between groups. Overall cohort stratified } \\
\text { according to weight loss: loss } \geq 5 \% \text { body weight } \\
\text { vs. }<5 \% \text { led to improved insulin sensitivity } \\
(P=0.001) \text { and steatosis }(P=0.015) \text {; loss } \geq 9 \% \text { body } \\
\text { weight vs. }<9 \% \text { also led to improved ballooning } \\
(P=0.04) \text {, inflammation }(P=0.045) \text { and NAS } \\
(P=0.009) \text {. }\end{array}$ \\
\hline
\end{tabular}

\begin{tabular}{|c|c|c|c|}
\hline Lazo et al. ${ }^{21}$ (2010) & $\begin{array}{l}\text { Overweight adults } \\
\left(\mathrm{BMI} \geq 25 \mathrm{~kg} / \mathrm{m}^{2}\right) \\
\text { with T2DM who } \\
\text { underwent proton } \\
\text { magnetic resonance } \\
\text { spectroscopy of the } \\
\text { liver ( } \mathrm{n}=96)\end{array}$ & $\begin{array}{l}\text { Ancillary study linked to the "Look } \\
\text { AHEAD" RCT. Participants had } 12 \\
\text { months of either: } 1 \text { ) intensive lifestyle } \\
\text { intervention: moderate calorie } \\
\text { restriction (1,200-1,500 kcal/day } \\
\text { for individuals weighing }<114 \mathrm{~kg} \text {, } \\
1,500-1,800 \mathrm{kcal} / \text { day for those }>114 \\
\mathrm{~kg} ;<30 \% \text { calories from fat and }<10 \% \\
\text { from SFAs) and increased physical } \\
\text { activity; } 2) \text { general education }\end{array}$ & $\begin{array}{l}\text { Lifestyle intervention group vs. controls: lost on } \\
\text { average } 8.3 \% \text { of their body weight vs. } 0.03 \% \\
(P<0.001), \text { had significant improvements in } \mathrm{HbA1C} \\
(-0.7 \% \text { vs. }-0.2 \%, P=0.04) \text { and a greater decrease } \\
\text { in hepatic steatosis }(-50.8 \% \text { vs. }-22.8 \%, P=0.04) \text {. } \\
\text { Individuals who lost } \geq 10 \% \text { of their body weight } \\
\text { achieved a } 79.5 \% \text { reduction in steatosis vs. } 13.7 \% \\
\text { for those with little weight change }( \pm 1 \%) \text {. } \\
\text { NAFLD incidence was significantly lower in the } \\
\text { lifestyle intervention group compared to controls. }\end{array}$ \\
\hline Promrat et al. ${ }^{22}$ (2010) & $\begin{array}{l}\text { Obese adults (BMI } \\
\left.25-40 \mathrm{~kg} / \mathrm{m}^{2}\right) \text { with } \\
\text { biopsy-proven NASH } \\
(\mathrm{n}=31)\end{array}$ & $\begin{array}{l}\text { Randomized 2:1 to receive the } \\
\text { following for } 48 \text { weeks: } 1) \text { intensive } \\
\text { lifestyle intervention: moderate } \\
\text { hypocaloric diet }(1,000-1,200 \\
\text { kcal/day if baseline weight }<200 \\
\text { lb or 1,200-1,500/day if }>200 \text { lb), } \\
\text { with restrictions on fat intake, in } \\
\text { combination with physical activity; } \\
\text { 2) general education }\end{array}$ & $\begin{array}{l}\text { Lifestyle intervention group vs controls: lost on } \\
\text { average } 9.3 \% \text { of their body weight vs. } 0.2 \% \\
\text { ( } P=0.003) \text {, had significant improvements in their } \\
\text { NAS ( } 72 \% \text { vs. } 30 \%, P=0.03 \text { ). } \\
\% \text { weight reduction correlated significantly with } \\
\text { improvement in NAS (r }=0.497, P=0.007 \text { ). } \\
\text { Individuals achieving } \geq 7 \% \text { weight loss experienced } \\
\text { significant improvements in steatosis, lobular } \\
\text { inflammation, ballooning and NAS vs individuals } \\
\text { who lost }<7 \% \text {. }\end{array}$ \\
\hline Lin et al. ${ }^{156}$ (2009) & $\begin{array}{l}\text { Obese }\left(\mathrm{BMI}>30 \mathrm{~kg} / \mathrm{m}^{2}\right) \\
\text { Taiwanese adults } \\
(\mathrm{n}=132)\end{array}$ & $\begin{array}{l}\text { Randomized to receive the following } \\
\text { for } 12 \text { weeks: 1) very low calorie diet } \\
450 \mathrm{kcal} / \text { day (VLCD- } 450) \text {; } 2 \text { ) very low } \\
\text { calorie diet } 800 \mathrm{kcal} / \text { day (VLCD-800) } \\
\text { Both groups had } 2 \text { weeks run in of } \\
\text { 1,200 kcal/day }\end{array}$ & $\begin{array}{l}\text { The percentage change in body weight for the } \\
\text { groups was - } 9.1 \% \text { (VLCD-450) and -9.0\% (VLCD- } \\
800)(P=N S) \text {. The improvement rate of NAFLD } \\
\text { as determined by ultrasound was } 41.5 \% \text { in the } \\
\text { VLCD- } 450 \text { group and } 50.0 \% \text { in the VLCD- } 800 \\
\text { group. No serious adverse events were reported } \\
\text { in either group. }\end{array}$ \\
\hline
\end{tabular}

BMI, body mass index; IHTG, intrahepatic triglyceride; NASH, nonalcoholic steatohepatitis; NS, not significant; NAS, NASH histological activity score; T2DM, type 2 diabetes mellitus; AHEAD, Action for Health in Diabetes; RCT, randomized controlled trial; SFAs, saturated fatty acids; HbA1C, haemoglobin A1C; NAFLD, nonalcoholic fatty liver disease; VLCD, very low calorie diet. 
scores, whereas plant protein is inversely related. ${ }^{43}$ In a cross-sectional study, patients with NAFLD ate $27 \%$ more animal protein compared to controls $(P<0.001)$, with $46 \%$ of those in the highest quartile of consumption having NAFLD, compared with only $17 \%$ in the lowest quartile $(P=0.001) .{ }^{44} \mathrm{~A}$ follow-up study showed a significant association between total $(P=0.028)$, red and/or processed meat $(P=0.031)$ consumption with NAFLD and insulin resistance even after adjustment for BMI, physical activity, alcohol, energy, SFA and cholesterol intake. ${ }^{45}$

\section{Pathophysiology}

Red and processed meats likely lead to NAFLD, insulin resistance and T2DM as a result of their high content of SFAs, cholesterol, heme-iron, nitrates and nitrites, preservatives, advancedglycation end-products and branched chain amino acids (BCAAs). ${ }^{46}$ BCAAs, found in higher concentrations in animal protein, lead to impaired insulin sensitivity by recruiting mammalian target of rapamycin (mTOR) and assembling mTOR complex 1 in combination with insulin (Fig. 2). ${ }^{47}$ mTOR complex 1 induces sterol regulatory element-binding protein-1c (SREBP-1c) leading to DNL. ${ }^{48,49}$ Diets low in methionine (found predominantly in meat, fish and dairy products), can prevent the development of insulin resistance in animal models via activation of fibroblast growth factor 21 (FGF21), which inhibits SREBP-1, suppressing DNL while activating hepatic FFA oxidation; ${ }^{50-55}$ although it should be noted that in addition to methionine-rich diets, methionine-deficient and methionine and choline-deficient diets, can also induce NAFLD in the animal model as a result of their ability to promote lipid dysregulation and oxidative stress. ${ }^{56,57}$ Red and processed meats also contain high levels of phosphatidylcholine and L-carnitine, which are metabolized to trimethylamine (TMA) by gut microbiota (Fig. 2). TMA is oxidized in the liver by hepatic flavincontaining monooxygenases to form trimethylamine oxide (TMAO), which is then released into the circulation. TMAO promotes atherosclerosis via the up-regulation of multiple macrophage scavenger receptors, ${ }^{58,59}$ and high TMAO levels correlate with increased incidence of major cardiovascular events. ${ }^{60}$ It is hypothesized TMAO may promote NAFLD by altering the synthesis and transport of bile acids, decreasing the overall bile acid pool and reversing the direction of cholesterol transport and glucose and energy homeostasis. ${ }^{61}$ Indeed, plasma TMAO levels correlate with the presence and severity of biopsy proven NAFLD in a large Chinese adult population. ${ }^{61}$ Individuals eating a vegan diet have an altered intestinal microbiota composition compared to omnivores, with reduced capacity to produce TMAO. ${ }^{62}$

\section{Randomized controlled trial data}

It is therefore hypothesized that a vegetarian diet would be superior to an omnivorous diet in reversing NAFLD and metabolic parameters. ${ }^{63}$ This was not borne out, however, in a small randomized prospective study comparing the influence of a 6-week isocaloric high-protein diet using either plant or animal protein on

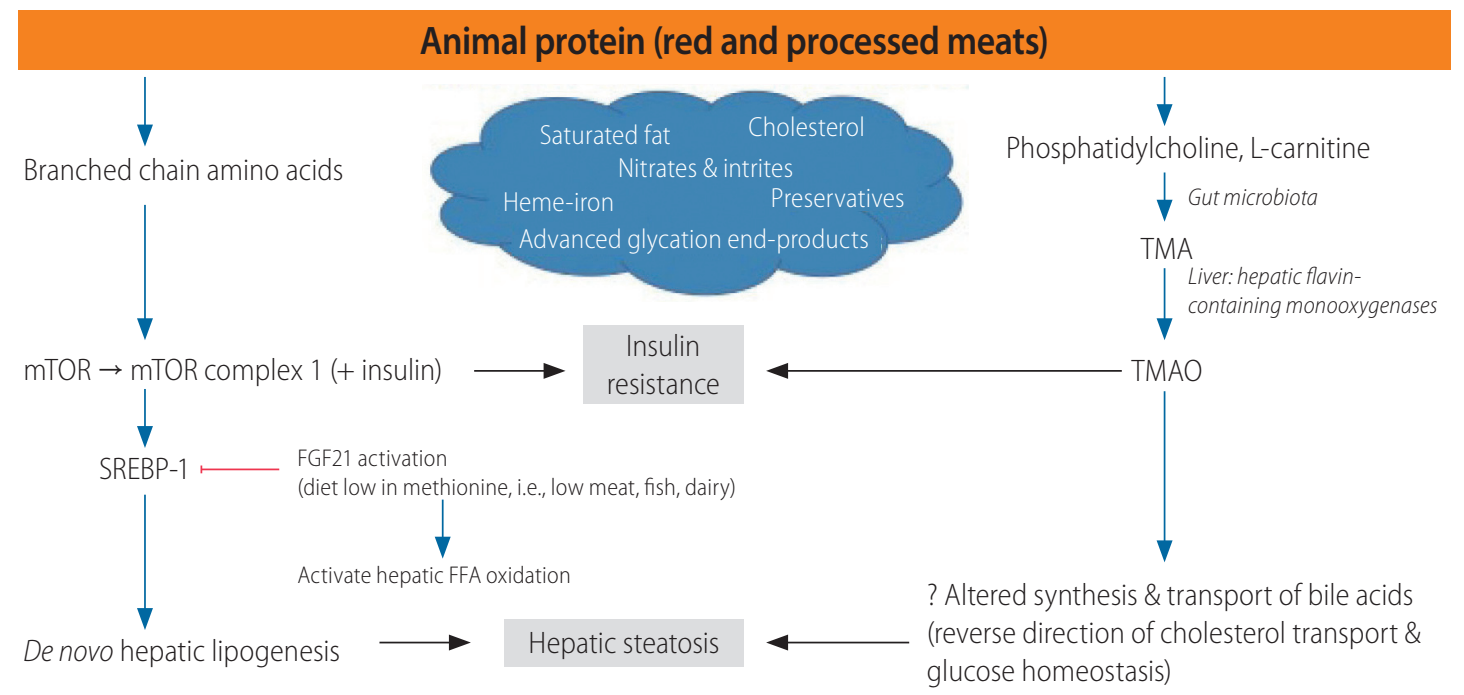

Figure 2. Potential mechanisms linking the consumption of animal protein with the development of NAFLD. TMA, trimethylamine; mTOR, mammalian target of rapamycin; TMAO, trimethylamine oxide; SREBP-1, sterol regulatory element-binding transcription factor 1c; FGF21, fibroblast growth factor 21; FFA, free fatty acid; NAFLD, nonalcoholic fatty liver disease. 
liver fat and lipogenic indices in patients with T2DM and NAFLD. While the high animal protein diet led to large postprandial increases in BCAA and methionine compared to the plant protein group, both groups experienced significant improvements in FGF21, reductions in liver fat and down-regulation of lipolysis. ${ }^{64}$ The results may have been similar due to small sample size and significant weight loss in both groups. Furthermore, the type of animal protein consumed (red, processed, lean) was not described.

\section{Clinical advice}

While large, prospective, RCTs are lacking to determine the impact of animal protein on the progression of NAFLD, it is reasonable to advise patients with NAFLD to reduce their intake of red and processed meats in light of their increased cardiovascular risk.

\section{CHOS}

\section{Observational studies}

Studies examining the association between CHOs and NAFLD are heterogeneous due to lack of differentiation between refined and unrefined CHOs. Low-diets have been associated with higher all-cause and cardiovascular mortality despite their benefits on initial weight loss, presumably due to reduced intake of unrefined CHOs (which are high in fiber, antioxidants, minerals, and vitamins), and increased consumption of animal protein, cholesterol and SFAs. ${ }^{65}$ In a small study evaluating intestinal permeability, patients with NAFLD were found to have significantly higher intake of protein and CHOs, specifically mono- and disaccharides, compared to controls. ${ }^{66}$ Protein and $\mathrm{CHO}$ intake correlated to higher alanine aminotransferase (ALT) levels in this group. High CHO intake ( $>70 \%$ of overall energy intake) has also been associated with higher aminotransferases and presence of the metabolic syndrome in a large Korean cohort, which persisted after adjustment for overall energy intake and BMI. ${ }^{67}$ The opposite was found in a Portugal cohort comparing the diets of 45 patients with NASH to 856 controls, where lower $\mathrm{CHO}$ consumption was seen in patients with NASH, although this was accompanied by other differences in dietary composition. ${ }^{68} \mathrm{~A}$ European cohort of 55 NAFLD patients and 88 controls found no significant differences in the relative intake of CHOs or fructose, although patients with NAFLD consumed more calories overall. ${ }^{16}$ In children, total $\mathrm{CHO}$ intake has also been shown to be significantly higher in obese children with NAFLD compared to those without. ${ }^{69} \mathrm{CHO}$ intake has also been shown to increase in parallel to the degree of liver fat detected by ultrasonography. ${ }^{69}$

No studies thus far directly compares the impact of refined versus unrefined CHOs on NAFLD, however there are several studies evaluating refined $\mathrm{CHO}$ alone. In two small studies, consumption of dietary fructose has been shown to be significantly higher among NAFLD patients compared to controls. ${ }^{70,71}$ SSBs, a surrogate for free sugars, have been associated with NAFLD in an Israeli population based study independent of age, gender, BMI and total caloric intake. ${ }^{44,72}$ In the Framingham Heart Study cohort, higher consumption of SSBs incrementally increased the odds ratio for NAFLD across quartiles of consumption, even after adjustment for BMI, energy intake, dietary fiber, fat, protein and diet soda. ${ }^{72}$ SSB consumption was also positively associated with ALT levels in this group. After controlling for dietary composition and physical activity, SSB consumption has been shown to be an independent variable to predict NAFLD with sensitivity of $100 \%$, specificity $76 \%$, positive predictive value $57 \%$ and negative predictive of $100 \%{ }^{73}$

The data on histologic impact of $\mathrm{CHO}$ consumption is limited. When comparing nutrient intake of 28 patients with biopsy-proven NASH to 18 with simple steatosis, those with NASH had higher intake of $\mathrm{CHOs}$, specifically simple $\mathrm{CHOs} .{ }^{74}$ In a bariatric surgery cohort, higher $\mathrm{CHO}$ intake was significantly associated with inflammation, but not fibrosis, on liver biopsy. ${ }^{7}$ In older adults with NAFLD, higher daily fructose consumption has been associated with fibrosis, hepatic inflammation and hepatocyte ballooning. ${ }^{75}$

\section{Pathophysiology}

CHOs induce DNL by activating the $\mathrm{CHO}$ responsive transcription factor, CHO response element binding protein (Fig. 1). ${ }^{76}$ Fructose is metabolized predominantly in the liver where it is converted into glyceraldehyde-3-phosphate, which can be used for gluconeogenesis or acetyl-CoA production. ${ }^{77}$ The latter can be oxidized, or used for lipogenesis. Diets high in fructose contribute to NAFLD by increasing DNL and reducing fatty acid oxidation. ${ }^{78-81}$ Fructose can also activate fatty acid synthase and stearoyl-COAdesaturase-1, ${ }^{82}$ sensitizing the liver towards inflammation, which may promote the development of $\mathrm{NASH}^{83}$ Although data are lacking, unrefined $\mathrm{CHO}$ s are likely to be protective against NAFLD as a result of their low glycemic index, high fiber content, and role in increasing production of short-chain fatty acids in the gut. ${ }^{84}$ 


\section{Randomized controlled trial data}

Several RCTs have been performed to evaluate the effects of a low CHO diet ( $<50 \%$ of daily calories) on NAFLD. In attempt to consolidate the data, a meta-analysis of 10 RCTs was performed, however significant heterogeneity was encountered. ${ }^{85}$ The overall conclusion was that a low $\mathrm{CHO}$ diet could reduce intrahepatic lipid content (IHLC) by over 10\%, however significant weight loss across all intervention groups limited the ability to isolate the effects of a low $\mathrm{CHO}$ diet alone. Two of the trials evaluated a ketogenic diet ( $8 \%$ CHO in one, $<20 \mathrm{~g} \mathrm{CHO}$ per day in the other) over 2 and 24 weeks, respectively. ${ }^{86,87}$ Despite weight loss in both, there was no significant reduction in ALT, however the 2 weeks study did show reduction in liver fat content. When low ( $<60 \mathrm{~g} / \mathrm{day})$ and high CHO (>180 g/day) diets were compared over an 11 weeks calorie restriction intervention, reduction in IHLC was comparable between both groups after $7 \%$ weight loss. ${ }^{24}$ Furthermore, a direct comparison of hypocaloric diets (30\% energy restricted) either low in CHO (and high in fat), or low in fat in 170 overweight individuals for 6 months, revealed comparable decreases in body weight, visceral fat and IHLC. ${ }^{88} \mathrm{~A}$ meta-analysis of 13 trials with a total of 260 participants reported an association between a high fructose diet and NAFLD incidence and severity. ${ }^{89}$ Only seven of these trials were isocaloric however, and in these studies fructose had no significant effect on IHLC or ALT. ${ }^{89}$ Unfortunately the majority of studies were small, of short duration and marred by confounding factors. Similarly a subsequent meta-analysis of 21 interventional studies found only low levels of evidence that a high fructose diet was associated with increased liver fat content and transaminases as studies were significantly confounded by excess energy intake. ${ }^{90}$

In adolescent boys, those on a limited free sugar diet ( $<5 \%$ daily calories) for 8 weeks experienced a significant decrease in hepatic steatosis and aminotransferases compared to those with no dietary intervention, though weight loss was greater in the intervention cohort. ${ }^{91}$ Focusing specifically on fructose reduction (by $50 \%$ ), a small pilot study showed reduction in IHLC and aminotransferases over 6 months. ${ }^{92}$ Results are difficult to interpret given lack of control group as well as significant reduction in weight, SFA and sucrose intake. Over-feeding studies further highlight the association between SSB and NAFLD. When randomized to $1 \mathrm{~L}$ daily of sugar sweetened soda, skim milk, diet soda, or water for 6 months, those consuming the sugar sweetened soda had significant increases in IHLC, visceral fat, and skeletal muscle fat, compared to no changes in the other groups, despite no significant weight changes ${ }^{93}$ After overfeeding overweight adults with 1,000 $\mathrm{kcal} /$ day of candy or SSBs for 3 weeks, body weight increased by $2 \%$ accompanied by $27 \%$ increase in IHLC. ${ }^{94}$ IHLC returned to baseline once baseline weight was achieved over the following 6 months. Whole, unrefined $\mathrm{CHO}$ s are protective against cardiovascular disease, T2DM, colorectal and breast cancer, ${ }^{95}$ and are associated with decreased all-cause mortality, ${ }_{1}^{96}$ however data in NAFLD is lacking.

\section{Clinical advice}

Clinicians should advise reduction in refined CHOs, specifically fructose, in patients with NAFLD.

\section{FIBER}

\section{Observational studies}

High fiber consumption is associated with a $15-30 \%$ decrease in all-cause and cardiovascular-related mortality, lower risk of heart disease, stroke, T2DM and gastro-intestinal cancer. ${ }^{95}$ Epidemiological studies suggest there may be an association between a low fiber diet and the development of NAFLD. In a study of 45 patients with NASH and over 800 controls, more than onethird of patients with NASH consumed lower than the recommended requirements of fiber, although this did not reach statistical significance compared to the controls unless the consumption of soluble fiber was considered in isolation (in this case nearly $90 \%$ of patients consumed less than $10 \mathrm{~g} / \mathrm{day}){ }^{68}$ Similarly, in an observational study of 55 NAFLD patients and 88 controls, NAFLD patients were found to consume less fiber. ${ }^{16}$ These findings were supported by a case-control study from Iran (NAFLD, $n=159$; controls, $n=158){ }_{1}^{97}$ however both studies are limited by differing macronutrient composition compared to controls. Fiber consumption has also been shown to be significantly lower in obese children with moderate and severe hepatic steatosis, compared to obese children without NAFLD. ${ }^{69}$ In a small uncontrolled pilot study, liver enzymes normalized in $75 \%$ of NAFLD patients eating $10 \mathrm{~g} /$ day of soluble fiber for 3 months. ${ }^{98}$ This study is limited not only by lack of a control group, but also reduction in BMI, waist circumference, insulin resistance index and cholesterol levels in two thirds of patients. 


\section{Pathophysiology}

The majority of studies looking at the benefits of fiber on cardiovascular risk factors have focused on soluble fiber. Soluble fiber is thought to be protective against NAFLD by reducing serum low-density lipoprotein (LDL)-cholesterol levels. ${ }^{99}$ The mechanism for this is unclear, although it has been proposed that soluble fiber may bind to bile acids or cholesterol during the formation of micelles, lowering the cholesterol concentration in hepatocytes, leading to up-regulation of LDL receptors and clearance of LDLcholesterol. ${ }^{100}$ Soluble fiber can also slow the rate at which $\mathrm{CHO}$ are absorbed into the circulation reducing post-prandial hyperglycemia, i.e., high fiber foods have a low glycemic index leading to improved glucose tolerance. ${ }^{101}$

\section{Randomized controlled trial data}

RCTs studying the effect of fiber intake in isolation on NAFLD are lacking, as this usually forms part of a wider dietary intervention. In one study, 70 obese individuals with features of the metabolic syndrome were randomized to two energy-restricted diets for 6 months. ${ }^{102}$ Participants who consumed higher levels of fiber from fruit experienced improvements in their FLI, hepatic steatosis index, NAFLD liver fat score and liver enzymes, supporting the consumption of fiber in the context of energy restriction for patients with NAFLD. In a small, randomized double-blind crossover trial, seven patients with NASH received $16 \mathrm{~g} /$ day of oligofructose (a prebiotic fiber), or placebo for 8 weeks. Oligofructose led to a significant reduction in insulin levels, as well as ALT and aspartate aminotransferase after 4 and 8 weeks, respectively, independent of a significant effect on plasma lipids. ${ }^{103}$

\section{Clinical advice}

Increasing fiber intake by increasing intake of fruits, vegetables, whole grains and legumes, should be encouraged in patients with NAFLD.

\section{FATS}

\section{Observational studies}

There is a strong degree of concordance between observational studies to show that a higher intake of SFAs, ${ }^{68,69,74,97,104}$ and a lower intake of polyunsaturated fatty acids (PUFAs), ${ }^{69,74,04}$ is associated with NAFLD and NASH. In a cohort of 25 patients with NASH and $25 \mathrm{BMI}$ matched controls, 7-day alimentary records revealed that patients with NASH consumed significantly higher proportions of SFAs and a lower percentage of PUFAs, although differences were also seen between their intake of cholesterol, fiber and anti-oxidant vitamins. ${ }^{104}$ The ratio of PUFAs to SFAs was also

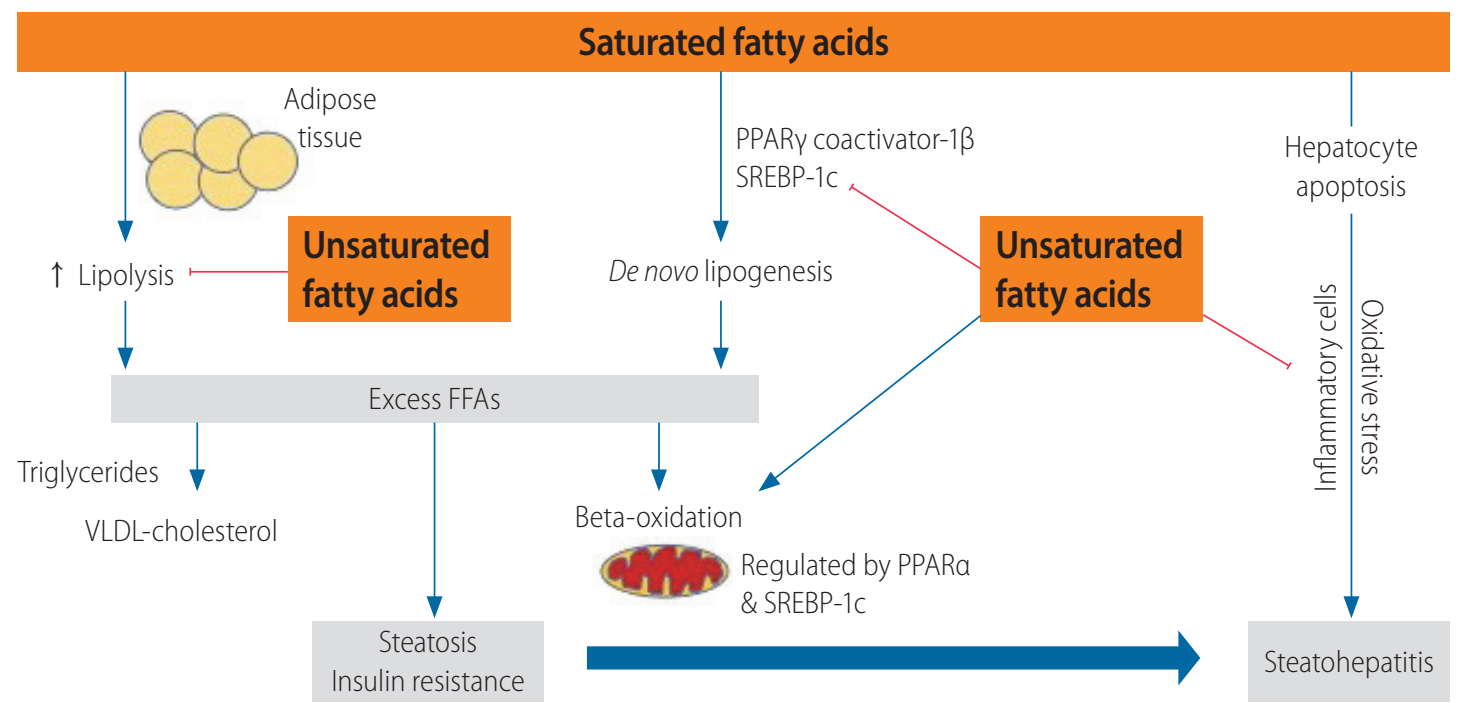

Figure 3. Mechanisms via which saturated and unsaturated fatty acids influence the pathogenesis of NAFLD. PPAR, peroxisome proliferator-activated receptor; FFAs, free fatty acids; VLDL, very low density lipoprotein; SREBP-1c, sterol regulatory element-binding protein-1c; NAFLD, nonalcoholic fatty liver disease. 
lower in patients with NASH and NAFLD compared to the general population in a Japanese cohort. ${ }^{74}$ These findings were replicated in pediatric cohort in which SFA intake correlated proportionally to the degree of hepatic steatosis. ${ }^{69}$ Furthermore, omega-3 fatty acid consumption was lower in pediatric NAFLD patients and this, along with insulin resistance, remained the most significant factor following multiple regression analysis. Cortez-Pinto et al. ${ }^{68}$ also reported higher total fat consumption in NASH patients compared to controls, including higher consumption of omega- 6 fatty acids, which differs from other studies. This study may have been confounded by differences in $\mathrm{CHO}$ and fiber consumption between groups.

\section{Pathophysiology}

SFAs exert their effects on the liver through the promotion of insulin resistance and oxidative stress. They induce hepatic steato- sis by increasing lipolysis as well as DNL, which occurs through the promotion of the transcription of peroxisome proliferator-activated receptor (PPAR) $\gamma$ coactivator-1 $\beta$ and SREBP-1C (Fig. 3). ${ }^{105}$ SFAs also promote lipotoxicity through ceramides and diacylglycerides, ${ }^{106}$ and can induce hepatocyte apoptosis and increase oxidative stress, which may encourage progression towards NASH. ${ }^{107}$ Conversely, monounsaturated fatty acids (MUFAs) activate transcription factors PPARY and PPARa, promoting safe fatty acid storage in adipose tissue and lipid detoxification via fatty acid oxidation, respectively. ${ }^{108}$ PUFAs increase the transcription of PPARa, increasing lipid metabolism and mitochondrial oxidation, thereby reducing hepatic FFA concentrations. ${ }^{109,110}$ They also inhibit SREBP$1 c$, reducing fatty acid synthesis. ${ }^{111,112}$ Omega-3 fatty acids lower the hepatic triglyceride content by suppressing hepatic VLDL apolipoprotein B-100, ${ }^{113}$ and inhibit inflammatory cells involved in NASH. ${ }^{114}$

Table 2. Summary of randomized controlled trial data examining the influence of diets high in saturated fatty acids and poly-and mono-unsaturated fatty acids on hepatic steatosis

\begin{tabular}{|c|c|c|c|}
\hline Study & Participant & Intervention & Result \\
\hline Bozzetto et al. ${ }^{119}$ (2012) & Adults with T2DM $(n=45)$ & $\begin{array}{l}8 \text { weeks diet, either: 1) high- } \\
\text { carbohydrate/high-fiber/low-glycemic } \\
\text { index diet; 2) high-MUFA diet; 3) high- } \\
\text { carbohydrate/high-fiber/low-glycemic } \\
\text { index diet plus physical activity; and } \\
\text { 4) high-MUFA diet plus physical activity }\end{array}$ & $\begin{array}{l}\text { An isocaloric diet high in MUFA led to a } \\
\text { reduction in liver fat, independent of weight } \\
\text { loss and exercise compared to patients } \\
\text { consuming a high-carbohydrate, high-fiber, } \\
\text { low-glycaemic index diet }\end{array}$ \\
\hline Bjermo et al. ${ }^{117}$ (2012) & $\begin{array}{l}\text { Obese adults (sagittal } \\
\text { abdominal diameter } \\
>25 \mathrm{~cm} \text {, or waist } \\
\text { circumference }>88 \mathrm{~cm} \\
\text { [women] or }>102 \mathrm{~cm} \\
\text { [men]; } \mathrm{n}=67 \text { ) }\end{array}$ & $\begin{array}{l}10 \text { weeks isocaloric diet high in omega } \\
6 \text { PUFAs or SFAs (butter); no other } \\
\text { changes to macronutrients }\end{array}$ & $\begin{array}{l}\text { A modest increase in weight was seen, } \\
\text { however this did not differ between groups. } \\
\text { The SFA group had significant increases } \\
\text { in liver fat (assessed using MRI), serum } \\
\text { triglycerides, total and LDL cholesterol and } \\
\text { insulin resistance compared to the group } \\
\text { receiving PUFAs, in which all these markers } \\
\text { improved. }\end{array}$ \\
\hline Rosqvist et al. ${ }^{116}$ (2014) & $\begin{array}{l}\text { Young, normal weight } \\
\text { adults }(n=39)\end{array}$ & $\begin{array}{l}750 \text { extra kcal/day for } 7 \text { weeks from } \\
\text { muffins high in SFAs vs. muffins high in } \\
\text { PUFAs }\end{array}$ & $\begin{array}{l}\text { The SFA group had greater increases in liver } \\
\text { fat }(P=0.033) \text { and a } 2 \text {-fold increase in VAT } \\
(P=0.035) \text {. The PUFA group had a 3-fold } \\
\text { increase in lean tissue ( } P=0.015) \text {. }\end{array}$ \\
\hline Errazuriz et al. ${ }^{118}$ (2017) & $\begin{array}{l}\text { Adults with pre-diabetes } \\
(\mathrm{n}=43)\end{array}$ & $\begin{array}{l}12 \text { week isocaloric weight-maintaining } \\
\text { diets: 1) high MUFAs (olive oil), 2) fiber- } \\
\text { rich, and 3) standard US food }\end{array}$ & $\begin{array}{l}\text { Only the MUFA group demonstrated a } \\
\text { significant decrease in liver fat fraction as } \\
\text { determined by MRI ( } P<0.0003) \text {, in addition } \\
\text { to improvements in hepatic and total insulin } \\
\text { sensitivity. }\end{array}$ \\
\hline $\begin{array}{l}\text { Luukkonen et al. }{ }^{115} \\
\text { (2018) }\end{array}$ & $\begin{array}{l}\text { Overweight adults (mean } \\
\text { BMI, } 31 \pm 1 \mathrm{~kg} / \mathrm{m}^{2} ; \mathrm{n}=38 \text { ) }\end{array}$ & $\begin{array}{l}\text { 1,000 extra kcal/day for } 3 \text { weeks from } \\
\text { either SFAs/unsaturated fat/simple } \\
\text { sugars }\end{array}$ & $\begin{array}{l}\text { Overeating } 1,000 \mathrm{kcal} / \mathrm{day} \text { of SFAs increased } \\
\text { IHTG more than unsaturated fats ( } 55 \% \text { vs. } \\
15 \%, P<0.05 \text { ). }\end{array}$ \\
\hline
\end{tabular}

T2DM, type 2 diabetes mellitus; MUFA, monounsaturated fatty acids; PUFAs, polyunsaturated fatty acids; SFAs, saturated fatty acids; MRI, magnetic resonance imaging; LDL, low-density lipoprotein; VAT, visceral adipose tissue; US, United States; BMI, body mass index; IHTG, intrahepatic triglyceride. 


\section{Randomized controlled trial data}

The beneficial effects of PUFAs and MUFAs, and metabolically harmful effects of SFAs, are shown in Table 2. ${ }^{115-119}$ Two metaanalyses have examined the effects of omega-3 supplementation on NAFLD. ${ }^{120,121}$ The number of eligible studies analysed were nine and 10, respectively (335 individuals and 577 individuals with NAFLD). Both reported that omega-3 supplementation was beneficial in reducing liver fat (predominantly quantified using ultrasound), but did not impact liver biochemistry. The analyses, however, were limited by poor quality study design and heterogeneity. It was not possible to comment on an optimal dose. In terms of histology, a trial comparing the effect of a diet high in PUFAs vs. placebo for 1 year in individuals with NASH revealed no significant difference in NAS ( $\geq 2$ point reduction) despite a greater reduction in liver fat in the treatment group, although participant numbers were small $(n=34){ }^{122}$

\section{Clinical advice}

Clinicians should advise patients with NAFLD to replace dietary SFAs with PUFAs or MUFAs.

\section{DIETS}

The Dietary Approaches to Stop Hypertension (DASH) diet is a low-glycemic, low energy-dense diet characterized by high intake of fruits and vegetables, whole grains, and low fat dairy products, with limited SFAs. An RCT comparing patients with NAFLD eating the DASH diet versus a control diet for 8 weeks (both of which contained $52-55 \%$ CHOs, $16-18 \%$ protein, 30\% fat and approximately $1,900 \mathrm{kcal} / \mathrm{day})$, showed that the DASH group had significantly greater reduction in aminotransferases and metabolic markers, including serum triglycerides, total cholesterol, VLDL cholesterol, high sensitivity c-reactive protein, insulin and Homeostatic Model Assessment of Insulin Resistance (HOMA-IR). ${ }^{123}$ The data are confounded by greater weight loss in patients following the DASH diet, however the high fiber and antioxidant content, and low saturated fat and refined CHOs content, is likely to be beneficial for NAFLD.

Soy is also thought to be helpful in NAFLD by inhibiting SREBP1c and activating PPARa, reducing lipid deposition and increasing antioxidant capacity. A three-arm RCT comparing patients eating a low calorie diet to a low-CHO, low calorie diet to a low- $\mathrm{CHO}$, low calorie, soy-containing diet, reported that individuals eating the soy-containing diet had significantly greater improvements in liver tests and serum insulin levels. ${ }^{124}$

While RCT data is sparse, research suggests that the Mediterranean diet (rich in plant-based foods, legumes and unsaturated fats) should prove ideal for patients with NAFLD as a result of its effectiveness as a form of primary prevention for components of the metabolic syndrome, and ability to reduce insulin resistance, liver fat and inflammation. ${ }^{125} \mathrm{An}$ ad libitum Mediterranean diet

Table 3. Suggested research priorities

\begin{tabular}{|c|c|}
\hline Nutrient of interest & Research question \\
\hline Protein & $\begin{array}{l}\text { 1. Does plant-based protein offer any benefit over lean animal protein (i.e., chicken/fish) in the prevention of NAFLD, } \\
\text { cirrhosis, HCC, or liver-related mortality? } \\
\text { 2. What is the impact of red and processed meat, lean meat, and plant protein on the histologic features of NASH? }\end{array}$ \\
\hline Carbohydrate & $\begin{array}{l}\text { 1. Does a diet high in whole grains offer any protection against NAFLD and progression to cirrhosis, HCC, or liver-related } \\
\text { mortality? } \\
\text { 2. What is the impact of refined versus unrefined carbohydrates on the histologic features of NASH? } \\
\text { 3. What is the impact of a diet low in free sugars on the histologic features of NASH? }\end{array}$ \\
\hline Fiber & $\begin{array}{l}\text { 1. Are high fiber diets protective from developing NAFLD, cirrhosis, HCC, or liver-related mortality? } \\
\text { 2. Can increasing fiber in the diet reduce hepatic steatosis and improve histologic features of NASH, with or without } \\
\text { weight loss? } \\
\text { 3. Is there a difference in the impact of insoluble and soluble fiber on reversing NAFLD? }\end{array}$ \\
\hline Fat & $\begin{array}{l}\text { 1. Can diets high in unsaturated fat prevent fibrosis progression or even reverse fibrosis? } \\
\text { 2. What is the impact of saturated versus unsaturated fat on the histologic features of NASH? }\end{array}$ \\
\hline Diets & $\begin{array}{l}\text { 1. Can a plant-based diet reverse histologic features of NASH without weight loss? } \\
\text { 2. Can any of these diets lead to fibrosis reversal without weight loss? } \\
\text { 3. Are these diets sustainable in this population long term? }\end{array}$ \\
\hline
\end{tabular}

NAFLD, nonalcoholic fatty liver disease; HCC, hepatocellular carcinoma; NASH, nonalcoholic steatohepatitis. 
compared to a low-fat diet showed similar reductions in hepatic steatosis over 12 weeks with similar weight loss in both groups. The Mediterranean group alone, however, saw improvements in cholesterol, triglycerides and hemoglobin $\mathrm{A} 1 \mathrm{C} .^{126}$ Furthermore, obese individuals with diabetes asked to follow a modified Mediterranean diet for 12 months were found to display lower levels of ALT compared to participants allocated to the American Diabetes Association diet and a low glycaemic index diet. ${ }^{127}$ The Mediterranean diet is now recommended by EASL for the management of NAFLD. ${ }^{14}$

\section{Clinical advice}

For patients with NAFLD we recommend diets high in whole, unprocessed foods, fiber, and unsaturated fats, with limited quantities of red and processed meats, refined $\mathrm{CHO}$ and saturated fat. Example diets include the Mediterranean diet, DASH diet, and other plant-based diets.

\section{BEVERAGES}

Two large systematic reviews have shown that coffee leads to a relative risk reduction of cirrhosis and liver-related mortality secondary to all causes. ${ }^{128,129}$ In terms of NAFLD, two meta-analysis have demonstrated that coffee can reduce the incidence of NAFLD, in addition to decreasing the risk of liver fibrosis among patients with established NAFLD. ${ }^{130,131}$ A non-linearity curve relationship between coffee consumption and the development of NAFLD is described, with more than 3 cups per day reducing the incidence of NAFLD significantly. ${ }^{130}$ Several constituents found within coffee have been postulated as being mechanistic due to their favourable effects on glucose metabolism. ${ }^{132}$ For example, chlorogenic acid inhibits glucose-6-phosphate hydrolysis, leading to a reduction in gluconeogenesis and glycogenolysis, and can inhibit glucose absorption from the gut. ${ }^{133}$

Concomitant alcohol consumption is frequently encountered in patients with NAFLD. Previous meta-analyses have shown no association between alcohol intake (up to $80 \mathrm{~g} /$ day) and hepatic steatosis, $^{134}$ and a protective effect for individuals drinking up to $40 \mathrm{~g} / \mathrm{day}^{135}$ however these studies were largely heterogenous, retrospective and subject to selection bias. A cross-sectional study concluded that steatosis is present in nearly $95 \%$ of obese persons who drink more than $60 \mathrm{~g}$ of alcohol per day, however obesity plays the over-arching role. ${ }^{136}$ There is, however, strong evi- dence that patients drinking excessively ( $\geq 2$ drinks/day for women and $\geq 3$ drinks/day for men) with NAFLD are at significantly increased risk of developing advanced liver fibrosis and this should therefore be discouraged. ${ }^{137}$ Even mild to moderate drinking ( $<210 \mathrm{~g} /$ week) has been found to increase the risk of steatohepatitis, fibrosis, decompensated liver disease, mortality and liver cancer among individuals with obesity and diabetes, ${ }^{138-144}$ although there is some disagreement among studies. ${ }^{135,145,146} \mathrm{Ab}$ stinence has been advocated for patients with NASH cirrhosis in order to reduce the risk for decompensation and hepatocellular carcinoma $(\mathrm{HCC})^{147}$

\section{Clinical advice}

Coffee consumption is protective against the development of NAFLD and disease progression. Moderate to heavy alcohol consumption should be avoided in the presence of obesity, NAFLD, and other metabolic risk factors. Abstinence is advised for patients with advanced fibrosis.

\section{LIMITATIONS OF CURRENT DATA}

One of the biggest challenges encountered when studying dietary determinants of diseases is the confounding effects of other dietary components and lifestyle factors. This may not be easily handled by multivariable analyses alone and can lead to erroneous conclusions. These issues were recently demonstrated in a series of meta-analyses which concluded that red or processed meat may only lead to small differences in the risk of all-cause mortality, cardiometabolic outcomes and cancer incidence, ${ }^{148-151}$ in contrast to the established medical opinion and public beliefs. Three of the reviews were reliant on observational studies for which many received low GRADE scores in terms of evidence quality. The authors identified fundamental issues inherent to the design of many nutritional studies including a lack of a clear hypothesis, selective reporting of results, reliance on self-reported food consumption, lack of controls and failure to address confounders. ${ }^{152,153}$ A review of RCT data comparing diets with differing amounts of red meat consumed for at least 6 months was similarly afflicted by poor quality evidence and discordant results. ${ }^{150}$ These results were used to inform guidelines published by the Nutritional Recommendations (NutriRECS) Consortium, which are the first to suggest there is no need for adults to reduce their consumption of red and processed meat, ${ }^{154}$ and have received widespread public 
criticism. It is vital that we are able to provide the public with accurate information about their dietary choices and maintain the integrity of evidence-based medicine. There therefore needs to be radical reform in terms of how these studies are undertaken. Small, poorly design observational studies are perhaps damaging to these field; instead investment is required in high quality large RCTs looking at long term outcomes, in addition to the collection of longitudinal data on markers of early disease. We have summarized these research priorities in Table 3.

\section{CONCLUSION}

This review has highlighted a significant lack of high quality RCT data in this field, offering a number of research opportunities for the future. Although well intentioned, diets focusing specifically on reducing $\mathrm{CHO}$ or fat intake miss out on the benefits of whole grains, fiber, and unsaturated fats, which do not need to be minimized in the diet. These diets are also not sustainable. Instead, the focus should shift to a lifestyle that incorporates healthy CHOs and fats, which may be more sustainable long term. Overall the current data is supportive of diets low in SFAs, red and processed meats, and refined CHOs for NAFLD. Diets that incorporate these recommendations include plant-based diets such as the DASH, Mediterranean, vegetarian, and vegan diets.

\section{Authors' contributions}

Theresa J. Hydes: Drafting the article, critical revision of the article and final approval of the version to be published

Sujan Ravi: Drafting the article, critical revision of the article and final approval of the version to be published

Rohit Loomba: Critical revision of the article and final approval of the version to be published

Meagan E. Gray: Conception and design, drafting the article, critical revision of the article and final approval of the version to be published

\section{Acknowledgements}

No grant or financial support of any of the authors is related to this work. MG receives funding support from NIDDK (R01DK108353). RL receives funding support from NIEHS (5P42ES010337), NCATS (5UL1TR001442), NIDDK (R01DK106419, P30DK120515), and DOD PRCRP (CA170674P2). Potential competing interests: MG serves as an advisory board member for Intercept. RL serves as a consultant or advisory board member for Arrowhead Pharmaceu- ticals, AstraZeneca, Bird Rock Bio, Boehringer Ingelheim, BristolMyer Squibb, Celgene, Cirius, CohBar, Conatus, Eli Lilly, Galmed, Gemphire, Gilead, Glympse bio, GNI, GRI Bio, Intercept, Ionis, Janssen Inc., Merck, Metacrine, Inc., NGM Biopharmaceuticals, Novartis, Novo Nordisk, Pfizer, Prometheus, Sanofi, Siemens, and Viking Therapeutics. In addition, his institution has received grant support from Allergan, Boehringer-Ingelheim, Bristol-Myers Squibb, Cirius, Eli Lilly and Company, Galectin Therapeutics, Galmed Pharmaceuticals, GE, Genfit, Gilead, Intercept, Grail, Janssen, Madrigal Pharmaceuticals, Merck, NGM Biopharmaceuticals, NuSirt, Pfizer, pH Pharma, Prometheus, and Siemens. He is also co-founder of Liponexus, Inc.

\section{Conflicts of Interest}

The authors have no conflicts to disclose.

\section{REFERENCES}

1. Sayiner M, Koenig A, Henry L, Younossi ZM. Epidemiology of nonalcoholic fatty liver disease and nonalcoholic steatohepatitis in the United States and the rest of the world. Clin Liver Dis 2016;20:205214

2. Vernon G, Baranova A, Younossi ZM. Systematic review: the epidemiology and natural history of non-alcoholic fatty liver disease and non-alcoholic steatohepatitis in adults. Aliment Pharmacol Ther 2011;34:274-285.

3. Leite NC, Salles GF, Araujo AL, Villela-Nogueira CA, Cardoso $C R$. Prevalence and associated factors of non-alcoholic fatty liver disease in patients with type-2 diabetes mellitus. Liver Int 2009;29: 113-119.

4. Prashanth M, Ganesh HK, Vima MV, John M, Bandgar T, Joshi SR, et al. Prevalence of nonalcoholic fatty liver disease in patients with type 2 diabetes mellitus. J Assoc Physicians India 2009;57:205210.

5. Boza C, Riquelme A, Ibañez L, Duarte I, Norero E, Viviani $P$, et al. Predictors of nonalcoholic steatohepatitis (NASH) in obese patients undergoing gastric bypass. Obes Surg 2005;15:1148-1153.

6. Haentjens P, Massaad D, Reynaert H, Peeters E, Van Meerhaeghe A, Vinken $S$, et al. Identifying non-alcoholic fatty liver disease among asymptomatic overweight and obese individuals by clinical and biochemical characteristics. Acta Clin Belg 2009;64:483-493.

7. Machado M, Marques-Vidal P, Cortez-Pinto H. Hepatic histology in obese patients undergoing bariatric surgery. J Hepatol 2006;45: 600-606.

8. Colicchio P, Tarantino G, del Genio F, Sorrentino P, Saldalamacchia $G$, Finelli $C$, et al. Non-alcoholic fatty liver disease in young 
Theresa J. Hydes, et al.

adult severely obese non-diabetic patients in south Italy. Ann Nutr Metab 2005;49:289-295.

9. Beymer C, Kowdley KV, Larson A, Edmonson P, Dellinger EP, Flum DR. Prevalence and predictors of asymptomatic liver disease in patients undergoing gastric bypass surgery. Arch Surg 2003;138:1240-1244.

10. Donnelly KL, Smith $\mathrm{Cl}$, Schwarzenberg SJ, Jessurun J, Boldt MD, Parks EJ. Sources of fatty acids stored in liver and secreted via lipoproteins in patients with nonalcoholic fatty liver disease. J Clin Invest 2005;115:1343-1351.

11. Sanyal AJ, Campbell-Sargent C, Mirshahi F, Rizzo WB, Contos MJ, Sterling RK, et al. Nonalcoholic steatohepatitis: association of insulin resistance and mitochondrial abnormalities. Gastroenterology 2001;120:1183-1192

12. Lambert JE, Ramos-Roman MA, Browning JD, Parks EJ. Increased de novo lipogenesis is a distinct characteristic of individuals with nonalcoholic fatty liver disease. Gastroenterology 2014;146:726735.

13. Chalasani N, Younossi Z, Lavine JE, Charlton M, Cusi K, Rinella M, et al. The diagnosis and management of nonalcoholic fatty liver disease: practice guidance from the American Association for the study of liver diseases. Hepatology 2018;67:328-357.

14. European Association for the Study of the Liver (EASL); European Association for the Study of Diabetes (EASD); European Association for the Study of Obesity (EASO). EASL-EASD-EASO clinical practice guidelines for the management of non-alcoholic fatty liver disease. J Hepatol 2016;64:1388-1402.

15. Vilar-Gomez E, Martinez-Perez Y, Calzadilla-Bertot L, TorresGonzalez A, Gra-Oramas B, Gonzalez-Fabian L, et al. Weight loss through lifestyle modification significantly reduces features of nonalcoholic steatohepatitis. Gastroenterology 2015;149:367-378.e5.

16. Wehmeyer $M H$, Zyriax BC, Jagemann B, Roth E, Windler E, Schulze zur Wiesch J, et al. Nonalcoholic fatty liver disease is associated with excessive calorie intake rather than a distinctive dietary pattern. Medicine (Baltimore) 2016;95:e3887.

17. Huang MA, Greenson JK, Chao C, Anderson L, Peterman D, Jacobson J, et al. One-year intense nutritional counseling results in histological improvement in patients with non-alcoholic steatohepatitis: a pilot study. Am J Gastroenterol 2005;100:1072-1081.

18. Parker R. The role of adipose tissue in fatty liver diseases. Liver Res 2018;2:35-42.

19. Abenavoli L, Peta V. Role of adipokines and cytokines in nonalcoholic fatty liver disease. Rev Recent Clin Trials 2014;9:134-140.

20. Tilg $H$, Moschen AR, Roden M. NAFLD and diabetes mellitus. Nat Rev Gastroenterol Hepatol 2017;14:32-42.

21. Lazo M, Solga SF, Horska A, Bonekamp S, Diehl AM, Brancati $\mathrm{FL}$, et al. Effect of a 12-month intensive lifestyle intervention on hepatic steatosis in adults with type 2 diabetes. Diabetes Care
2010;33:2156-2163.

22. Promrat $K$, Kleiner DE, Niemeier HM, Jackvony E, Kearns M, Wands $J R$, et al. Randomized controlled trial testing the effects of weight loss on nonalcoholic steatohepatitis. Hepatology 2010;51:121-129.

23. Ueno T, Sugawara H, Sujaku K, Hashimoto O, Tsuji R, Tamaki S, et al. Therapeutic effects of restricted diet and exercise in obese patients with fatty liver. J Hepatol 1997;27:103-107.

24. Kirk E, Reeds DN, Finck BN, Mayurranjan SM, Patterson BW, Klein S. Dietary fat and carbohydrates differentially alter insulin sensitivity during caloric restriction. Gastroenterology 2009;136:1552-1560.

25. Musso G, Cassader M, Rosina F, Gambino R. Impact of current treatments on liver disease, glucose metabolism and cardiovascular risk in non-alcoholic fatty liver disease (NAFLD): a systematic review and meta-analysis of randomised trials. Diabetologia 2012;55:885-904

26. Jensen MD, Ryan DH, Apovian CM, Ard JD, Comuzzie AG, Donato KA, et al. 2013 AHA/ACC/TOS guideline for the management of overweight and obesity in adults: a report of the American College of Cardiology/American Heart Association task force on practice guidelines and the obesity society. Circulation 2014;129(25 suppl 2):S102-S138.

27. Rynders CA, Thomas EA, Zaman A, Pan Z, Catenacci VA, Melanson EL. Effectiveness of intermittent fasting and time-restricted feeding compared to continuous energy restriction for weight loss. Nutrients 2019;11:2442.

28. Johari MI, Yusoff K, Haron J, Nadarajan C, Ibrahim KN, Wong MS, et al. A randomised controlled trial on the effectiveness and adherence of modified alternate-day calorie restriction in improving activity of non-alcoholic fatty liver disease. Sci Rep 2019;9:11232.

29. Cai H, Qin YL, Shi ZY, Chen JH, Zeng MJ, Zhou W, et al. Effects of alternate-day fasting on body weight and dyslipidaemia in patients with non-alcoholic fatty liver disease: a randomised controlled trial. BMC Gastroenterol 2019;19:219.

30. Cross AJ, Leitzmann MF, Gail MH, Hollenbeck AR, Schatzkin A, Sinha R. A prospective study of red and processed meat intake in relation to cancer risk. PLoS Med 2007;4:e325.

31. Pan A, Sun Q, Bernstein AM, Schulze MB, Manson JE, Stampfer MJ, et al. Red meat consumption and mortality: results from 2 prospective cohort studies. Arch Intern Med 2012;172:555-563.

32. Sinha R, Cross AJ, Graubard BI, Leitzmann MF, Schatzkin A. Meat intake and mortality: a prospective study of over half a million people. Arch Intern Med 2009;169:562-571.

33. Rohrmann S, Overvad K, Bueno-de-Mesquita HB, Jakobsen MU, Egeberg R, Tjønneland $A$, et al. Meat consumption and mortalityresults from the European prospective investigation into cancer and nutrition. BMC Med 2013;11:63.

34. Etemadi A, Sinha R, Ward MH, Graubard BI, Inoue-Choi M, Dawsey $\mathrm{SM}$, et al. Mortality from different causes associated with meat, 
heme iron, nitrates, and nitrites in the NIH-AARP diet and health study: population based cohort study. BMJ 2017;357:j1957.

35. Bellavia A, Stilling F, Wolk A. High red meat intake and all-cause cardiovascular and cancer mortality: is the risk modified by fruit and vegetable intake? Am J Clin Nutr 2016;104:1137-1143.

36. van den Brandt PA. Red meat, processed meat, and other dietary protein sources and risk of overall and cause-specific mortality in the Netherlands cohort study. Eur J Epidemiol 2019;34:351-369.

37. Abete I, Romaguera D, Vieira AR, Lopez de Munain A, Norat T. Association between total, processed, red and white meat consumption and all-cause, CVD and IHD mortality: a meta-analysis of cohort studies. Br J Nutr 2014;112:762-775.

38. Larsson SC, Orsini N. Red meat and processed meat consumption and all-cause mortality: a meta-analysis. Am J Epidemiol 2014;179:282-289.

39. Wang $X$, Lin $X$, Ouyang YY, Liu J, Zhao G, Pan A, et al. Red and processed meat consumption and mortality: dose-response meta-analysis of prospective cohort studies. Public Health Nutr 2016;19:893-905.

40. Takata Y, Shu XO, Gao YT, Li H, Zhang X, Gao J, et al. Red meat and poultry intakes and risk of total and cause-specific mortality: results from cohort studies of Chinese adults in Shanghai. PLOS One 2013:8:e56963.

41. Song M, Fung TT, Hu FB, Willett WC, Longo VD, Chan AT, et al. Association of animal and plant protein intake with all-cause and cause-specific mortality. JAMA Intern Med 2016;176:1453-1463.

42. Alferink LJ, Kiefte-de Jong JC, Erler NS, Veldt BJ, Schoufour JD, de Knegt RJ, et al. Association of dietary macronutrient composition and non-alcoholic fatty liver disease in an ageing population: the Rotterdam Study. Gut 2019;68:1088-1098.

43. Rietman A, Sluik D, Feskens EJM, Kok FJ, Mensink M. Associations between dietary factors and markers of NAFLD in a general Dutch adult population. Eur J Clin Nutr 2018;72:117-123.

44. Zelber-Sagi S, Nitzan-Kaluski D, Goldsmith R, Webb M, Blendis L, Halpern $Z$, et al. Long term nutritional intake and the risk for nonalcoholic fatty liver disease (NAFLD): a population based study. J Hepatol 2007;47:711-717.

45. Zelber-Sagi S, Ivancovsky-Wajcman D, Fliss Isakov N, Webb M, Orenstein $\mathrm{D}$, Shibolet $\mathrm{O}$, et al. High red and processed meat consumption is associated with non-alcoholic fatty liver disease and insulin resistance. J Hepatol 2018;68:1239-1246.

46. Wolk A. Potential health hazards of eating red meat. J Intern Med 2017;281:106-122.

47. Menon S, Dibble CC, Talbott G, Hoxhaj G, Valvezan AJ, Takahashi $\mathrm{H}$, et al. Spatial control of the TSC complex integrates insulin and nutrient regulation of mTORC1 at the lysosome. Cell 2014;156:771785.

48. Kim JB, Sarraf P, Wright M, Yao KM, Mueller E, Solanes G, et al. Nutritional and insulin regulation of fatty acid synthetase and leptin gene expression through ADD1/SREBP1. J Clin Invest 1998;101:1-9.

49. Li S, Brown MS, Goldstein JL. Bifurcation of insulin signaling pathway in rat liver: mTORC1 required for stimulation of lipogenesis, but not inhibition of gluconeogenesis. Proc Natl Acad Sci U S A 2010;107:3441-3446.

50. Laeger T, Henagan TM, Albarado DC, Redman LM, Bray GA, Noland RC, et al. FGF21 is an endocrine signal of protein restriction. J Clin Invest 2014;124:3913-3922.

51. Gallinetti J, Harputlugil E, Mitchell JR. Amino acid sensing in dietary-restriction-mediated longevity: roles of signal-transducing kinases GCN2 and TOR. Biochem J 2013;449:1-10.

52. Holland WL, Adams AC, Brozinick JT, Bui HH, Miyauchi Y, Kusminski CM, et al. An FGF21-adiponectin-ceramide axis controls energy expenditure and insulin action in mice. Cell Metab 2013;17:790797.

53. Nishimura T, Nakatake Y, Konishi M, Itoh N. Identification of a novel FGF, FGF-21, preferentially expressed in the liver. Biochim Biophys Acta 2000;1492:203-206.

54. Domouzoglou EM, Maratos-Flier E. Fibroblast growth factor 21 is a metabolic regulator that plays a role in the adaptation to ketosis. Am J Clin Nutr 2011;93:901S-905S.

55. Xu J, Lloyd DJ, Hale C, Stanislaus S, Chen M, Sivits G, et al. Fibroblast growth factor 21 reverses hepatic steatosis, increases energy expenditure, and improves insulin sensitivity in diet-induced obese mice. Diabetes 2009;58:250-259.

56. Aissa AF, Tryndyak V, de Conti A, Melnyk S, Gomes TD, Bianchi ML, et al. Effect of methionine-deficient and methionine-supplemented diets on the hepatic one-carbon and lipid metabolism in mice. Mol Nutr Food Res 2014;58:1502-1512.

57. Weltman MD, Farrell GC, Liddle C. Increased hepatocyte CYP2E1 expression in a rat nutritional model of hepatic steatosis with inflammation. Gastroenterology 1996;111:1645-1653.

58. Wang Z, Klipfell E, Bennett BJ, Koeth R, Levison BS, DuGar B, et al. Gut flora metabolism of phosphatidylcholine promotes cardiovascular disease. Nature 2011;472:57-63.

59. Koeth RA, Wang Z, Levison BS, Buffa JA, Org E, Sheehy BT, et al. Intestinal microbiota metabolism of L-carnitine, a nutrient in red meat, promotes atherosclerosis. Nat Med 2013;19:576-585.

60. Tang WH, Wang Z, Levison BS, Koeth RA, Britt EB, Fu X, et al. Intestinal microbial metabolism of phosphatidylcholine and cardiovascular risk. N Engl J Med 2013;368:1575-1584.

61. Chen YM, Liu Y, Zhou RF, Chen XL, Wang C, Tan XY, et al. Associations of gut-flora-dependent metabolite trimethylamine- $\mathrm{N}$-oxide, betaine and choline with non-alcoholic fatty liver disease in adults. Sci Rep 2016;6:19076.

62. Wu GD, Compher C, Chen EZ, Smith SA, Shah RD, Bittinger K, et 
Theresa J. Hydes, et al. Evidence-based nutritional advice for NAFLD

al. Comparative metabolomics in vegans and omnivores reveal constraints on diet-dependent gut microbiota metabolite production. Gut 2016:65:63-72.

63. McCarty MF. GCN2 and FGF21 are likely mediators of the protection from cancer, autoimmunity, obesity, and diabetes afforded by vegan diets. Med Hypotheses 2014;83:365-371.

64. Markova M, Pivovarova O, Hornemann S, Sucher S, Frahnow T, Wegner $\mathrm{K}$, et al. Isocaloric diets high in animal or plant protein reduce liver fat and inflammation in individuals with type 2 diabetes. Gastroenterology 2017;152:571-585.e8.

65. Noto H, Goto A, Tsujimoto T, Noda M. Low-carbohydrate diets and all-cause mortality: a systematic review and meta-analysis of observational studies. PLoS One 2013;8:e55030.

66. Volynets V, Küper MA, Strahl S, Maier IB, Spruss A, Wagnerberger $S$, et al. Nutrition, intestinal permeability, and blood ethanol levels are altered in patients with nonalcoholic fatty liver disease (NAFLD). Dig Dis Sci 2012;57:1932-1941.

67. Kwon OW, Jun DW, Lee SM, Lee KN, Lee HL, Lee OY, et al. Carbohydrate but not fat is associated with elevated aminotransferases. Aliment Pharmacol Ther 2012;35:1064-1072.

68. Cortez-Pinto H, Jesus L, Barros H, Lopes C, Moura MC, Camilo ME. How different is the dietary pattern in non-alcoholic steatohepatitis patients? Clin Nutr 2006;25:816-823.

69. Papandreou D, Karabouta Z, Pantoleon A, Rousso I. Investigation of anthropometric, biochemical and dietary parameters of obese children with and without non-alcoholic fatty liver disease. Appetite 2012;59:939-944.

70. Ouyang X, Cirillo P, Sautin Y, McCall S, Bruchette JL, Diehl AM, et al. Fructose consumption as a risk factor for non-alcoholic fatty liver disease. J Hepatol 2008;48:993-999.

71. Thuy S, Ladurner R, Volynets V, Wagner S, Strahl S, Königsrainer A, et al. Nonalcoholic fatty liver disease in humans is associated with increased plasma endotoxin and plasminogen activator inhibitor 1 concentrations and with fructose intake. J Nutr 2008;138:14521455.

72. Ma J, Fox CS, Jacques PF, Speliotes EK, Hoffmann U, Smith CE, et al. Sugar-sweetened beverage, diet soda, and fatty liver disease in the Framingham Heart Study cohorts. J Hepatol 2015;63:462-469.

73. Assy N, Nasser G, Kamayse I, Nseir W, Beniashvili Z, Djibre A, et al. Soft drink consumption linked with fatty liver in the absence of traditional risk factors. Can J Gastroenterol 2008;22:811-816.

74. Toshimitsu K, Matsuura B, Ohkubo I, Niiya T, Furukawa S, Hiasa $Y$, et al. Dietary habits and nutrient intake in non-alcoholic steatohepatitis. Nutrition 2007;23:46-52.

75. Abdelmalek MF, Suzuki A, Guy C, Unalp-Arida A, Colvin R, Johnson RJ, et al. Increased fructose consumption is associated with fibrosis severity in patients with nonalcoholic fatty liver disease. Hepatology 2010;51:1961-1971.
76. Ma L, Tsatsos NG, Towle HC. Direct role of ChREBP.Mlx in regulating hepatic glucose-responsive genes. J Biol Chem 2005;280: 12019-12027.

77. Alwahsh SM, Gebhardt R. Dietary fructose as a risk factor for nonalcoholic fatty liver disease (NAFLD). Arch Toxicol 2017;91:15451563.

78. Stanhope KL, Schwarz JM, Keim NL, Griffen SC, Bremer AA, Graham JL, et al. Consuming fructose-sweetened, not glucosesweetened, beverages increases visceral adiposity and lipids and decreases insulin sensitivity in overweight/obese humans. J Clin Invest 2009;119:1322-1334.

79. Dirlewanger $M$, Schneiter $P$, Jéquier $E$, Tappy $L$. Effects of fructose on hepatic glucose metabolism in humans. Am J Physiol Endocrinol Metab 2000;279:E907-E911.

80. Pollock NK, Bundy V, Kanto W, Davis CL, Bernard PJ, Zhu H, et al. Greater fructose consumption is associated with cardiometabolic risk markers and visceral adiposity in adolescents. J Nutr 2012;142:251-257.

81. Schwarz JM, Noworolski SM, Wen MJ, Dyachenko A, Prior JL, Weinberg ME, et al. Effect of a high-fructose weight-maintaining diet on lipogenesis and liver fat. J Clin Endocrinol Metab 2015;100:2434-2442.

82. Crescenzo R, Bianco F, Falcone I, Coppola P, Liverini G, Iossa S. Increased hepatic de novo lipogenesis and mitochondrial efficiency in a model of obesity induced by diets rich in fructose. Eur J Nutr 2013;52:537-545.

83. Renaud HJ, Cui JY, Lu H, Klaassen CD. Effect of diet on expression of genes involved in lipid metabolism, oxidative stress, and inflammation in mouse liver-insights into mechanisms of hepatic steatosis. PLoS One 2014;9:e88584.

84. Ross AB, Godin JP, Minehira K, Kirwan JP. Increasing whole grain intake as part of prevention and treatment of nonalcoholic fatty liver disease. Int J Endocrinol 2013;2013:585876.

85. Haghighatdoost F, Salehi-Abargouei A, Surkan PJ, Azadbakht L. The effects of low carbohydrate diets on liver function tests in nonalcoholic fatty liver disease: a systematic review and meta-analysis of clinical trials. J Res Med Sci 2016;21:53.

86. Browning JD, Baker JA, Rogers T, Davis J, Satapati S, Burgess SC. Short-term weight loss and hepatic triglyceride reduction: evidence of a metabolic advantage with dietary carbohydrate restriction. Am J Clin Nutr 2011;93:1048-1052.

87. Tendler D, Lin S, Yancy WS Jr, Mavropoulos J, Sylvestre P, Rockey $D C$, et al. The effect of a low-carbohydrate, ketogenic diet on nonalcoholic fatty liver disease: a pilot study. Dig Dis Sci 2007;52:589593.

88. Haufe S, Engeli S, Kast P, Böhnke J, Utz W, Haas V, et al. Randomized comparison of reduced fat and reduced carbohydrate hypocaloric diets on intrahepatic fat in overweight and obese human 
subjects. Hepatology 2011;53:1504-1514.

89. Chiu S, Sievenpiper JL, de Souza RJ, Cozma Al, Mirrahimi A, Carleton $\mathrm{AJ}$, et al. Effect of fructose on markers of non-alcoholic fatty liver disease (NAFLD): a systematic review and meta-analysis of controlled feeding trials. Eur J Clin Nutr 2014;68:416-423.

90. Chung M, Ma J, Patel K, Berger S, Lau J, Lichtenstein AH. Fructose, high-fructose corn syrup, sucrose, and nonalcoholic fatty liver disease or indexes of liver health: a systematic review and metaanalysis. Am J Clin Nutr 2014;100:833-849.

91. Schwimmer JB, Ugalde-Nicalo P, Welsh JA, Angeles JE, Cordero $M$, Harlow KE, et al. Effect of a low free sugar diet vs usual diet on nonalcoholic fatty liver disease in adolescent boys: a randomized clinical trial. JAMA 2019;321:256-265.

92. Volynets V, Machann J, Küper MA, Maier IB, Spruss A, Königsrainer $A$, et al. A moderate weight reduction through dietary intervention decreases hepatic fat content in patients with non-alcoholic fatty liver disease (NAFLD): a pilot study. Eur J Nutr 2013;52:527-535.

93. Maersk M, Belza A, Stødkilde-Jørgensen H, Ringgaard S, Chabanova $E$, Thomsen $H$, et al. Sucrose-sweetened beverages increase fat storage in the liver, muscle, and visceral fat depot: a 6-mo randomized intervention study. Am J Clin Nutr 2012;95:283-289.

94. Sevastianova K, Santos A, Kotronen A, Hakkarainen A, Makkonen J, Silander $\mathrm{K}$, et al. Effect of short-term carbohydrate overfeeding and long-term weight loss on liver fat in overweight humans. Am J Clin Nutr 2012;96:727-734.

95. Reynolds A, Mann J, Cummings J, Winter N, Mete E, Te Morenga L. Carbohydrate quality and human health: a series of systematic reviews and meta-analyses. Lancet 2019;393:434-445.

96. Zong G, Gao A, Hu FB, Sun Q. Whole grain intake and mortality from all causes, cardiovascular disease, and cancer: a metaanalysis of prospective cohort studies. Circulation 2016;133:23702380.

97. Zolfaghari H, Askari G, Siassi F, Feizi A, Sotoudeh G. Intake of nutrients, fiber, and sugar in patients with nonalcoholic fatty liver disease in comparison to healthy individuals. Int J Prev Med 2016;7:98.

98. Rocha R, Cotrim HP, Siqueira AC, Floriano S. Non alcoholic fatty liver disease: treatment with soluble fibres. Arq Gastroenterol 2007:44:350-352.

99. Truswell AS. Dietary fibre and plasma lipids. Eur J Clin Nutr 1995;49 Suppl 3:S105-S109.

100. Anderson JW, Tietyen-Clark J. Dietary fiber: hyperlipidemia, hypertension, and coronary heart disease. Am J Gastroenterol 1986;81:907-919.

101. Björck I, Elmståhl HL. The glycaemic index: importance of dietary fibre and other food properties. Proc Nutr Soc 2003;62:201-206.

102. Cantero I, Abete I, Monreal JI, Martinez JA, Zulet MA. Fruit fiber consumption specifically improves liver health status in obese sub- jects under energy restriction. Nutrients 2017;9:667.

103. Daubioul CA, Horsmans Y, Lambert P, Danse E, Delzenne NM. Effects of oligofructose on glucose and lipid metabolism in patients with nonalcoholic steatohepatitis: results of a pilot study. Eur J Clin Nutr 2005;59:723-726.

104. Musso G, Gambino R, De Michieli F, Cassader M, Rizzetto M, Durazzo $M$, et al. Dietary habits and their relations to insulin resistance and postprandial lipemia in nonalcoholic steatohepatitis. Hepatology 2003;37:909-916.

105. Della Pepa G, Vetrani C, Lombardi G, Bozzetto L, Annuzzi G, Rivellese AA. Isocaloric dietary changes and non-alcoholic fatty liver disease in high cardiometabolic risk individuals. Nutrients 2017:9:1065.

106. Nolan CJ, Larter CZ. Lipotoxicity: why do saturated fatty acids cause and monounsaturates protect against it? J Gastroenterol Hepatol 2009;24:703-706.

107. Leamy AK, Egnatchik RA, Young JD. Molecular mechanisms and the role of saturated fatty acids in the progression of non-alcoholic fatty liver disease. Prog Lipid Res 2013;52:165-174.

108. Yokoi H, Mizukami H, Nagatsu A, Tanabe H, Inoue M. Hydroxy monounsaturated fatty acids as agonists for peroxisome proliferator-activated receptors. Biol Pharm Bull 2010;33:854-861.

109. Khan SA, Ali A, Khan SA, Zahran SA, Damanhouri G, Azhar E, et al. Unraveling the complex relationship triad between lipids, obesity, and inflammation. Mediators Inflamm 2014;2014:502749.

110. Stillwell W, Wassall SR. Docosahexaenoic acid: membrane properties of a unique fatty acid. Chem Phys Lipids 2003;126:1-27.

111. Caviglia JM, Gayet C, Ota T, Hernandez-Ono A, Conlon DM, Jiang $H$, et al. Different fatty acids inhibit apoB100 secretion by different pathways: unique roles for ER stress, ceramide, and autophagy. J Lipid Res 2011;52:1636-1651.

112. Schaeffer L, Gohlke H, Müller M, Heid IM, Palmer LJ, Kompauer I, et al. Common genetic variants of the FADS1 FADS2 gene cluster and their reconstructed haplotypes are associated with the fatty acid composition in phospholipids. Hum Mol Genet 2006;15:17451756.

113. Shearer GC, Savinova OV, Harris WS. Fish oil -- how does it reduce plasma triglycerides? Biochim Biophys Acta 2012;1821:843-851.

114. Scorletti E, Byrne CD. Omega-3 fatty acids, hepatic lipid metabolism, and nonalcoholic fatty liver disease. Annu Rev Nutr 2013:33:231-248.

115. Luukkonen PK, Sädevirta S, Zhou Y, Kayser B, Ali A, Ahonen L, et al. Saturated fat is more metabolically harmful for the human liver than unsaturated fat or simple sugars. Diabetes Care 2018:41:17321739.

116. Rosqvist $F$, Iggman $D$, Kullberg J, Cedernaes J, Johansson HE, Larsson $A$, et al. Overfeeding polyunsaturated and saturated fat causes distinct effects on liver and visceral fat accumulation in humans. 
Theresa J. Hydes, et al. Evidence-based nutritional advice for NAFLD

Diabetes 2014;63:2356-2368.

117. Bjermo H, Iggman D, Kullberg J, Dahlman I, Johansson L, Persson $L$, et al. Effects of $n-6$ PUFAs compared with SFAs on liver fat, lipoproteins, and inflammation in abdominal obesity: a randomized controlled trial. Am J Clin Nutr 2012;95:1003-1012.

118. Errazuriz I, Dube S, Slama M, Visentin R, Nayar S, O'Connor H, et al. Randomized controlled trial of a MUFA or fiber-rich diet on hepatic fat in prediabetes. J Clin Endocrinol Metab 2017;102:17651774.

119. Bozzetto L, Prinster A, Annuzzi G, Costagliola L, Mangione A, Vitelli $A$, et al. Liver fat is reduced by an isoenergetic MUFA diet in a controlled randomized study in type 2 diabetic patients. Diabetes Care 2012;35:1429-1435.

120. Parker HM, Johnson NA, Burdon CA, Cohn JS, O'Connor HT, George J. Omega-3 supplementation and non-alcoholic fatty liver disease: a systematic review and meta-analysis. J Hepatol 2012;56:944-951.

121. Lu W, Li S, Li J, Wang J, Zhang R, Zhou Y, et al. Effects of omega-3 fatty acid in nonalcoholic fatty liver disease: a meta-analysis. Gastroenterol Res Pract 2016;2016:1459790.

122. Argo CK, Patrie JT, Lackner C, Henry TD, de Lange EE, Weltman $A L$, et al. Effects of $n-3$ fish oil on metabolic and histological parameters in NASH: a double-blind, randomized, placebo-controlled trial. J Hepatol 2015;62:190-197.

123. Razavi Zade M, Telkabadi MH, Bahmani F, Salehi B, Farshbaf S, Asemi Z. The effects of DASH diet on weight loss and metabolic status in adults with non-alcoholic fatty liver disease: a randomized clinical trial. Liver Int 2016;36:563-571.

124. Kani AH, Alavian SM, Esmaillzadeh A, Adibi P, Azadbakht L. Effects of a novel therapeutic diet on liver enzymes and coagulating factors in patients with non-alcoholic fatty liver disease: a parallel randomized trial. Nutrition 2014;30:814-821.

125. Abenavoli L, Boccuto L, Federico A, Dallio M, Loguercio C, Di Renzo $L$, et al. Diet and non-alcoholic fatty liver disease: the mediterranean way. Int J Environ Res Public Health 2019;16:3011.

126. Ryan MC, Itsiopoulos C, Thodis T, Ward G, Trost N, Hofferberth S, et al. The Mediterranean diet improves hepatic steatosis and insulin sensitivity in individuals with non-alcoholic fatty liver disease. J Hepatol 2013;59:138-143.

127. Fraser A, Abel R, Lawlor DA, Fraser D, Elhayany A. A modified mediterranean diet is associated with the greatest reduction in alanine aminotransferase levels in obese type 2 diabetes patients: results of a quasi-randomised controlled trial. Diabetologia 2008;51:1616-1622.

128. Kennedy OJ, Roderick P, Buchanan R, Fallowfield JA, Hayes PC, Parkes J. Systematic review with meta-analysis: coffee consumption and the risk of cirrhosis. Aliment Pharmacol Ther 2016;43:562-574.

129. Saab S, Mallam D, Cox GA 2nd, Tong MJ. Impact of coffee on liver diseases: a systematic review. Liver Int 2014;34:495-504.

130. Chen YP, Lu FB, Hu YB, Xu LM, Zheng MH, Hu ED. A systematic review and a dose-response meta-analysis of coffee dose and nonalcoholic fatty liver disease. Clin Nutr 2019;38:2552-2557.

131. Wijarnpreecha K, Thongprayoon C, Ungprasert P. Coffee consumption and risk of nonalcoholic fatty liver disease: a systematic review and meta-analysis. Eur J Gastroenterol Hepatol 2017;29:e8-e12.

132. van Dijk AE, Olthof MR, Meeuse JC, Seebus E, Heine RJ, van Dam RM. Acute effects of decaffeinated coffee and the major coffee components chlorogenic acid and trigonelline on glucose tolerance. Diabetes Care 2009;32:1023-1025.

133. Herling AW, Burger HJ, Schwab D, Hemmerle H, Below P, Schubert $G$. Pharmacodynamic profile of a novel inhibitor of the hepatic glucose-6-phosphatase system. Am J Physiol 1998;274:G1087G1093.

134. Roerecke M, Nanau R, Rehm J, Neuman M. Ethnicity matters: a systematic review and meta-analysis of the non-linear relationship between alcohol consumption and prevalence and incidence of hepatic steatosis. EBioMedicine 2016;8:317-330.

135. Sookoian S, Castaño GO, Pirola CJ. Modest alcohol consumption decreases the risk of non-alcoholic fatty liver disease: a metaanalysis of 43175 individuals. Gut 2014;63:530-532.

136. Bellentani S, Saccoccio G, Masutti F, Crocè LS, Brandi G, Sasso F, et al. Prevalence of and risk factors for hepatic steatosis in northern Italy. Ann Intern Med 2000;132:112-117.

137. Khoudari G, Singh A, Noureddin M, Fritze D, Lopez R, Asaad I, et al. Characterization of patients with both alcoholic and nonalcoholic fatty liver disease in a large United States cohort. World J Hepatol 2019;11:710-718.

138. Åberg F, Helenius-Hietala J, Puukka P, Färkkilä M, Jula A. Interaction between alcohol consumption and metabolic syndrome in predicting severe liver disease in the general population. Hepatology 2018;67:2141-2149.

139. Hart CL, Morrison DS, Batty GD, Mitchell RJ, Davey Smith G. Effect of body mass index and alcohol consumption on liver disease: analysis of data from two prospective cohort studies. BMJ 2010;340:c1240.

140. Åberg F, Helenius-Hietala J, Puukka P, Jula A. Binge drinking and the risk of liver events: a population-based cohort study. Liver Int 2017;37:1373-1381.

141. Ruhl CE, Everhart JE. Joint effects of body weight and alcohol on elevated serum alanine aminotransferase in the United States population. Clin Gastroenterol Hepatol 2005;3:1260-1268.

142. Ekstedt M, Franzén LE, Holmqvist M, Bendtsen P, Mathiesen UL, Bodemar $\mathrm{G}$, et al. Alcohol consumption is associated with progression of hepatic fibrosis in non-alcoholic fatty liver disease. Scand J Gastroenterol 2009;44:366-374.

143. Åberg F, Puukka P, Salomaa V, Männistö S, Lundqvist A, Valsta L, 


\section{CLINICAL and MOLECULAR}

et al. Risks of light and moderate alcohol use in fatty liver disease: follow-up of population cohorts. Hepatology 2020;71:835-848.

144. Ajmera V, Belt $P$, Wilson LA, Gill RM, Loomba R, Kleiner DE, et al. Among patients with nonalcoholic fatty liver disease, modest alcohol use is associated with less improvement in histologic steatosis and steatohepatitis. Clin Gastroenterol Hepatol 2018;16:1511-1520. e5.

145. Hajifathalian K, Torabi Sagvand B, McCullough AJ. Effect of alcohol consumption on survival in nonalcoholic fatty liver disease: a national prospective cohort study. Hepatology 2019;70:511-521.

146. Dunn W, Sanyal AJ, Brunt EM, Unalp-Arida A, Donohue M, McCullough AJ, et al. Modest alcohol consumption is associated with decreased prevalence of steatohepatitis in patients with nonalcoholic fatty liver disease (NAFLD). J Hepatol 2012;57:384-391.

147. Ascha MS, Hanouneh IA, Lopez R, Tamimi TA, Feldstein AF, Zein NN. The incidence and risk factors of hepatocellular carcinoma in patients with nonalcoholic steatohepatitis. Hepatology 2010;51:1972-1978.

148. Zeraatkar D, Han MA, Guyatt GH, Vernooij RWM, El Dib R, Cheung $K$, et al. Red and processed meat consumption and risk for allcause mortality and cardiometabolic outcomes: a systematic review and meta-analysis of cohort studies. Ann Intern Med 2019;171:703710.

149. Han MA, Zeraatkar D, Guyatt GH, Vernooij RWM, El Dib R, Zhang $Y$, et al. Reduction of red and processed meat intake and cancer mortality and incidence: a systematic review and meta-analysis of cohort studies. Ann Intern Med 2019;171:711-720.

150. Zeraatkar D, Johnston BC, Bartoszko J, Cheung K, Bala MM, Valli C, et al. Effect of lower versus higher red meat intake on cardiometabolic and cancer outcomes: a systematic review of randomized trials. Ann Intern Med 2019;171:721-731.

151. Vernooij RWM, Zeraatkar D, Han MA, El Dib R, Zworth M, Milio $K$, et al. Patterns of red and processed meat consumption and risk for cardiometabolic and cancer outcomes: a systematic review and meta-analysis of cohort studies. Ann Intern Med 2019;171:732-741.

152. Carroll AE, Doherty TS. Meat consumption and health: food for thought. Ann Intern Med 2019;171:767-768.

153. Ioannidis JPA. The challenge of reforming nutritional epidemiologic research. JAMA 2018:320:969-970.

154. Johnston BC, Zeraatkar D, Han MA, Vernooij RWM, Valli C, El Dib $\mathrm{R}$, et al. Unprocessed red meat and processed meat consumption: dietary guideline recommendations from the nutritional recommendations (NutriRECS) consortium. Ann Intern Med 2019;171:756764.

155. Harrison SA, Fecht W, Brunt EM, Neuschwander-Tetri BA. Orlistat for overweight subjects with nonalcoholic steatohepatitis: a randomized, prospective trial. Hepatology 2009;49:80-86.

156. Lin WY, Wu CH, Chu NF, Chang CJ. Efficacy and safety of verylow-calorie diet in Taiwanese: a multicenter randomized, controlled trial. Nutrition 2009:25:1129-1136. 